\title{
Investigating a two-component model of solid fuel organic aerosol in London: processes, $\mathrm{PM}_{1}$ contributions, and seasonality
}

\author{
D. E. Young ${ }^{1, *}$, J. D. Allan ${ }^{1,2}$, P. I. Williams ${ }^{1,2}$, D. C. Green ${ }^{3}$, R. M. Harrison ${ }^{4,5}$, J. Yin ${ }^{4}$, M. J. Flynn ${ }^{1}$, \\ M. W. Gallagher ${ }^{1}$, and H. Coe ${ }^{1}$ \\ ${ }^{1}$ School of Earth, Atmospheric and Environmental Sciences, University of Manchester, Oxford Road, \\ Manchester, M13 9PL, UK \\ ${ }^{2}$ National Centre for Atmospheric Science, University of Manchester, Oxford Road, Manchester, M13 9PL, UK \\ ${ }^{3}$ School of Biomedical and Health Sciences, King's College London, London, UK \\ ${ }^{4}$ School of Geography, Earth and Environmental Sciences, University of Birmingham, Edgbaston, Birmingham, B15 2TT, UK \\ ${ }^{5}$ Department of Environmental Sciences / Center of Excellence in Environmental Studies, King Abdulaziz University, Jeddah, \\ 21589, Saudi Arabia \\ *now at: Department of Environmental Toxicology, University of California, Davis, CA 95616, USA
}

Correspondence to: H. Coe (hugh.coe@manchester.ac.uk)

Received: 30 July 2014 - Published in Atmos. Chem. Phys. Discuss.: 13 August 2014

Revised: 27 January 2015 - Accepted: 10 February 2015 - Published: 5 March 2015

\begin{abstract}
Solid fuel emissions, including those from biomass burning, are increasing in urban areas across the European Union due to rising energy costs and government incentives to use renewable energy sources for heating. In order to help protect human health as well as to improve air quality and pollution abatement strategies, the sources of combustion aerosols, their contributions, and the processes they undergo need to be better understood. A highresolution time-of-flight aerosol mass spectrometer (HRToF-AMS) was therefore deployed at an urban background site between January and February 2012 to investigate solid fuel organic aerosols (SFOA) in London. The variability of SFOA was examined and the factors governing the split between the two SFOA factors derived from Positive Matrix Factorisation (PMF) were assessed. The concentrations of both factors were found to increase during the night and during cold periods, consistent with domestic space heating activities. The split between the two factors is likely governed predominantly by differences in burn conditions where SFOA1 best represents more efficient burns and SFOA2 best represents less efficient burns. The differences in efficiency may be due to burner types or burn phase, for example. Different fuel types and levels of atmospheric processing also likely contribute to the two factors. As the mass spectral profile of SFOA is highly variable, the findings from this study
\end{abstract}

may have implications for improving future source apportionment and factorisation analyses.

During the winter, SFOA was found to contribute $38 \%$ to the total non-refractory submicron organic aerosol (OA) mass, with similar contributions from both SFOA factors (20\% from SFOA1 and $18 \%$ from SFOA2). A similar contribution of SFOA was derived for the same period from a compact time-of-flight AMS (cToF-AMS), which measured for a full calendar year at the same site. The seasonality of SFOA was investigated using the year-long data set where concentrations were greatest in the autumn and winter. During the summer, SFOA contributed $11 \%$ to the organic fraction, where emissions resulted from different anthropogenic activities such as barbecues and domestic garden wood burning. The significant contribution of SFOA to total organic mass throughout the year suggests that the negative effects on health and air quality, as well as climate, are not just confined to winter as exposure to these aerosols and the associated black carbon can also occur during the summer, which may have significant implications for air-quality policies and mitigation strategies. 


\section{Introduction}

The association between adverse health effects and ambient particles has long been recognised (e.g. Pope and Dockery, 2006), where regulations on particulate pollution are based on $\mathrm{PM}_{10}$ and more recently, $\mathrm{PM}_{2.5}$ (particulate matter (PM) with aerodynamic dynamic diameters less than 10 and $2.5 \mu \mathrm{m}$ respectively; European Union, 2008). Along with $\mathrm{PM}_{2.5}$, $\mathrm{PM}_{1}$ is also receiving greater attention from the air quality community, including the medical sector, as these particles can penetrate more deeply into the lungs. Particles less than $100 \mathrm{~nm}$ in diameter, termed nanoparticles, have the potential to enter the blood stream where they can be distributed throughout the body, causing further damage (Oberdörster et al., 2005). Furthermore, particle toxicity varies greatly with chemical composition, with smaller particles likely to be most detrimental to human health as they are typically composed of toxic constituents such as organics, secondary inorganics, and metals (Donaldson et al., 2003).

In addition to their effects on health, aerosol emissions from anthropogenic activities significantly contribute to poor air quality and visibility, frequently resulting in severe pollution events, particularly in urban areas (e.g. Dall'Osto et al., 2013; Zhang et al., 2014). Organic aerosols (OA) are of particular interest as they can often represent a substantial fraction, and up to $90 \%$, of total fine particulate mass depending on location (Kanakidou et al., 2005). In urban areas such as Paris and Cork during the winter, organic aerosols have been found to contribute 30-62\% to the total non-refractory $\mathrm{PM}_{1}$ (NR-PM 1 , Crippa et al., 2013; Dall'Osto et al., 2013; Young et al., 2014). Furthermore, meteorological conditions and boundary layer dynamics in the winter result in elevated concentrations of the primary fraction of OA, resulting in pollution events (Zhang et al., 2007). When the sources of primary organic aerosols (POA) are explored, transport, cooking, and solid fuel burning aerosols are found to contribute significantly to the total POA mass in urban areas (Allan et al., 2010; Mohr et al., 2012; Crippa et al., 2013; Dall'Osto et al., 2013).

Sources of combustion aerosols are frequently categorised into solid fuel, biofuel, biomass burning, and fossil fuel where solid fuel includes various types of solid material such as wood, coal, and peat, whereas biofuel refers to a solid, liquid, or gaseous fuel converted from biomass (e.g. Bond et al., 2004). Biomass burning often refers to wildfires and agricultural burning and fossil fuel includes coal or gas and is a natural fuel formed in the geological past from the remains of living organisms. It is important to make the distinction between the types of burning when identifying anthropogenic and biogenic sources of combustion aerosols and assessing the importance of emissions from the different sources due to their effects on air quality, health and climate (Szidat et al., 2006). Appropriate measures can then be taken to target specific sources to reduce emissions and address other abatement strategies, for example. Particulate emissions from burning biomass, wood, and coal as well as other fossil fuel combustion related activities such as vehicular transport, industry, and residential space heating are particularly important in terms of contributing to poor air quality. In the United Kingdom (UK) various legislative measures have been implemented to reduce emissions from such activities; the Low Emission Zone (LEZ; TfL, 2008), introduced across most of Greater London in 2008, aims to encourage cleaner transportation by reducing exhaust emissions from heavy diesel vehicles. The burning of coal by industry and domestic heating resulted in significant pollution events such as the Great Smog of 1952 in London, with coal combustion still playing a key role in wintertime pollution in China, contributing 15-17\% to NR-PM 1 (Sun et al., 2013; Zhang et al., 2014). Although still important, emissions from coal burning in the UK have decreased owing to the Clean Air Acts, where Smoke Control Areas were also introduced across the country. Only the burning of smokeless fuels is permitted in such areas, although some fuels, including seasoned wood, may be burned if carried out in approved burners (Defra, 2014). Wood burning is widely used in domestic heating across Europe (e.g. Finland, Hellén et al., 2008; Austria, Caseiro et al., 2009; Portugal, Borrego et al., 2010) with additional fuel types used in cooking stoves across the world (e.g. Washington, Maykut et al., 2003; China, Peabody et al., 2005) and is further suggested to be used within the UK as a source of secondary heating as well as for decoration (Fuller et al., 2014).

The LEZ and Smoke Control Areas have largely been successful, with reduced emissions in London from transport and smoke. However, a recent study (Fuller et al., 2013) suggested that such legislative measures may no longer be effective, with evidence of wood burning and solid fuel identified as a potential source of OA in many European cities (e.g. Oslo, Yttri et al., 2005; London, Allan et al., 2010; Barcelona, Mohr et al., 2012; Paris, Crippa et al., 2013; Cork, Dall'Osto et al., 2013). Burning in residential areas is difficult to control and with rising fossil fuel prices and government schemes encouraging the use of renewable energy sources such as biomass, emissions from solid fuel and wood burning are likely to increase over the coming years (Fuller et al., 2013). In Denmark, Glasius et al. (2006) found that increasing fossil fuel costs partly contributed to the doubling in wood-combustion stoves and boilers within a 10 -year period, a time when there were no regulations on the emissions from such activities.

Black carbon (BC) is strongly associated with combustion emissions, where the dominant source is from traffic emissions, although solid fuel and biomass burning sources have also been found to be important during the winter (Crilley et al., 2014; Liu et al., 2014). Wood burning emissions could be considered to be as important as traffic-related emissions in terms of their contribution to POA (Ries et al., 2009; Fuller et al., 2014), where the latter are more stringently regulated. As exposure to aerosols is ubiquitous, it is important to un- 
derstand aerosol sources, with better quantification of their concentrations to assess their role in pollution events and potential impacts to better inform abatement policies and strategies. Furthermore, as the contribution of solid fuel and other primary organic aerosols to the total aerosol loading is increasing, there are significant implications on human health (Bølling et al., 2009), air quality and climate.

The sources and contributions of combustion aerosols in London have been investigated as part of the ClearfLo project using various methods where Crilley et al. (2014) performed a multi-site $\mathrm{BC}$ comparison using the Aethalometer as well as ${ }^{14} \mathrm{C}$, levoglucosan and potassium measurements. Liu et al. (2014) used the single particle soot photometer (SP2) to characterise BC in London during winter. Furthermore, Mohr et al. (2013) used a micro-orifice volatilisation impactor high-resolution time-of-flight chemical ionisation mass spectrometer (MOVI-HRToF-CIMS) to investigate wood burning. In comparison, in this paper, we focus on the solid fuel component from Positive Matrix Factorisation (PMF) of the organic fraction of aerosol mass spectrometer (AMS) data from ClearfLo, where we investigate the sources of solid fuel aerosols and their contributions to total mass in a densely populated area. The high-resolution time-of-flight AMS (HR-ToF-AMS) was deployed for a 4week intensive measurement campaign during winter 2012, a time when solid fuel aerosols would be prominent. Furthermore, a compact time-of-flight AMS (cToF-AMS) was deployed at the same urban background site in London for a full calendar year (Young et al., 2014), allowing the temporal trends of submicron aerosols to be evaluated.

\section{Experimental}

\subsection{Sampling site}

A suite of state-of-the-art instrumentation, measuring aerosols, gases, radicals and meteorological parameters, was deployed for two major intensive observation periods (IOPs) during 2012 as part of the NERC-funded Clean Air for London (ClearfLo) Project (www.clearflo.ac.uk). Measurements were conducted in a residential area $7 \mathrm{~km}$ to the west of Central London at the ClearfLo urban background supersite in the grounds of a school in North Kensington $\left(51.521055^{\circ} \mathrm{N}, 0.213432^{\circ} \mathrm{W}\right)$. Long-term measurement campaigns also took place in various locations in and around London between 2011 and 2013 as part of this large, multiinstitutional collaborative scientific project based in the UK. Details on the ClearfLo experimental campaigns and locations are described in Bohnenstengel et al. (2015) and Young et al. (2014).

\subsection{Aerosol mass spectrometer measurements}

Aerosol chemical composition was measured by the highresolution time-of-flight AMS (HR-ToF-AMS, DeCarlo et al., 2006) during January and February 2012 and by the compact time-of-flight AMS (cToF-AMS, Drewnick et al., 2005) for a full calendar year (11 January 2012-23 January 2013). The HR-ToF-AMS was located in a shipping container containing several other aerosol instruments, where aerosols were sub-sampled from a sampling stack with a flow of $30 \mathrm{~L} \mathrm{~min}^{-1}$ via a $3.5 \mu \mathrm{m}$ cut-off cyclone. The cToFAMS sampled through a $\mathrm{PM}_{2.5}$ inlet, with a bypass flow of $16 \mathrm{~L} \mathrm{~min}^{-1}$ and split using an asymmetric Y-piece. In this study, 4 min averaged data were obtained by the HR-ToFAMS every $30 \mathrm{~min}$, as sampling occurred in an alternating sequence with other $\mathrm{BC}$ and aerosol volatility measurements using a thermodenuder (Huffman et al., 2008). The time resolution of the cToF-AMS was 5 min throughout the measurement period. An overview of the AMS can be found in Canagaratna et al. (2007), where details regarding the sampling protocol and data analysis procedures including the applied corrections, such as relative ionisation efficiencies and collection efficiency, can be found in Young et al. (2014). Details regarding the data pre-treatment and quality assurance for the data sets used in this study, including for Positive Matrix Factorisation (PMF) analysis, can also be found in Young et al. (2014) and the supporting information.

\subsection{Gas measurements}

CO was measured using an Aerolaser AL 5002 UV fluorescence instrument which was calibrated using an Air Products $200 \mathrm{ppb} \mathrm{CO}$ in air standard that was certified to NPL standards. $\mathrm{NO}$ and $\mathrm{NO}_{2}$ were measured using an Air Quality Design custom-built high-sensitivity chemiluminesence analyser with a Blue Light $\mathrm{NO}_{2}$ converter. The $\mathrm{NO}$ instrument was calibrated using a $5 \mathrm{ppm} \mathrm{NO}$ in nitrogen cylinder from BOC, which was diluted to $20 \mathrm{ppb}$ using scrubbed zero air (BOC BTCA 178). The $\mathrm{NO}_{2}$ instrument was calibrated using gas phase titration of the $\mathrm{NO}$ standard with $\mathrm{O}_{3}$.

\subsection{Levoglucosan and potassium ion measurements}

$24 \mathrm{~h} \mathrm{PM}_{2.5}$ samples were collected on quartz fibre filters (Whatman QM-A) using a high-volume Digitel DHA-80 sampler at a flow of $500 \mathrm{~L} \mathrm{~min}^{-1}$ and were analysed for wood smoke marker levoglucosan as described in Young et al. (2014) using a slightly modified version of the method of Yin et al. (2010) and Wagener et al. (2012).

Water-soluble potassium ion $\left(\mathrm{K}^{+}\right)$data were obtained using a small portion of the Digitel filter samples which was extracted with distilled de-ionised water $(10 \mathrm{~mL})$ by undergoing $40 \mathrm{~min}$ mechanical agitation to ensure thorough removal of the water-soluble aerosol. The resulting solutions were filtered and analysed for $\mathrm{K}^{+}$using a DIONEX ICS2000 ion chromatography system coupled with a gradient pump, which generates one eluent from two different solutions: de-ionised water and concentrated potassium hydroxide solution. The sample concentrations were calibrated with 
a series of mixed standards of known concentration (0.01$10 \mathrm{ppm})$.

\section{Results}

\subsection{Identification of the components of the organic fraction}

As part of PMF analysis one must go through a process to determine the most suitable number of factors (Ulbrich et al., 2009). Here, we show the steps we took to determine the number of factors where four main components were identified from PMF analysis on the organic fraction of the HRToF-AMS data from the winter IOP: hydrocarbon-like OA (HOA), cooking OA (COA), solid fuel OA (SFOA) and oxygenated OA (OOA), where an additional SFOA factor was identified from the 5-factor solution set. Both the 4- and 5factor solution sets produced data that satisfied the selection criteria for the appropriate number of factors and could be considered valid from various diagnostic tests, which assess the quality and suitability of the solution. The 6-factor solution was discarded due to its significant dependency on initialisation seed as well as the production of a factor that did not appear physically meaningful. The details of the PMF analysis are covered in a separate publication - see Sect. 5.1 in the Supplement of Young et al. (2014) for a detailed discussion on the number of factors chosen from the highresolution data set and the criteria used to select the best solution. Here we describe the methods used to choose between the 4- and 5-factor solutions.

Increasing the number of factors derived from PMF analysis of AMS data often improves mathematical PMF diagnostics used to select the appropriate solution set. However, the introduction of a new factor can sometimes result in a phenomenon known as "splitting" (Ulbrich et al., 2009), whereby factors that bear similar temporal and/or mass spectral profiles are representative of the variations within a single factor. Factors with varying profiles can manifest within PMF as rotational ambiguity, divergence, or factor mixing. Therefore, the comparison of retrieved factors with reference mass spectra and time series from ancillary measurements can determine their physical meaningfulness. This method of factorisation validation enabled Lanz et al. (2007) to split OOA into type 1 and type 2, which was the first time OOA2 had been reported in the literature. However, it is not always possible to separate OOA into its two subtypes if ambient temperature and chemistry are not sufficiently variable such as in the winter (e.g. Allan et al., 2010). OOA1 and OOA2 are now widely recognised as representing end members of OOA evolution where OOA1 is highly aged with low volatility and OOA2 is less processed and more volatile (e.g. Jimenez et al., 2009; $\mathrm{Ng}$ et al., 2010). In the literature, OOA1 and OOA2 are often referred to as low-volatility oxygenated organic aerosol (LV-OOA) and semi-volatile oxygenated organic aerosol (SV-OOA), respectively.

Therefore, in order to identify the most atmospherically reasonable solution set and further investigate the two SFOA factors from the 5-factor solution, comparisons were made with ancillary measurements. It has been shown that $\mathrm{NO}_{\mathrm{x}}$ and $\mathrm{CO}$ are strongly related to HOA (Zhang et al., 2005) as they are all emitted from fuel combustion in vehicle engines. However, traffic activity is not the only source of these gases, which are used as tracers for combustion. Space heating has been found to be another potential combustion source and therefore contributes to SFOA (Allan et al., 2010). The Pearson's $r$ values derived between the gas tracers and the SFOA factor from the 4-factor solution (hereon in termed SFOA$4 \mathrm{fac}$ ) are shown in Table 1. When the two SFOA factors from the 5-factor solution (SFOA-combined) are summed and compared to the gas tracers the Pearson's $r$ values are better than those for SFOA-4fac. However, as both traffic and domestic fuel burning from space heating contribute to $\mathrm{CO}$ and $\mathrm{NO}_{\mathrm{x}}$ concentrations, a multi-linear regression fit as detailed in Allan et al. (2010) was performed to assess the relative contributions of traffic (HOA) and wood burning (SFOA) to these trace gases.

Fitting was performed according to the function

$f(\mathrm{HOA}, \mathrm{SFOA})=A[\mathrm{HOA}]+B[\mathrm{SFOA}]+C$,

where $[\mathrm{HOA}]$ and $[\mathrm{SFOA}]$ are the predictor variables and are concentrations of the HOA and SFOA PMF factors. $A, B$ and $C$ are fitting parameters optimised to minimise the squared difference between $f(\mathrm{HOA}, \mathrm{SFOA})$ and $\mathrm{NO}_{\mathrm{x}}$ or $\mathrm{CO}$, where $\mathrm{NO}_{\mathrm{x}}$ and $\mathrm{CO}$ are the response variables. This multi-linear regression fit was performed on the HOA and SFOA factors from the 4-factor solution and the HOA and combined SFOA factors from the 5-factor solution. Using the multilinear regression fit, the $\mathrm{CO}$ and $\mathrm{NO}_{\mathrm{x}}$ concentrations were estimated and subsequently compared to the measured trace gas concentrations. A Pearson's $r$ value could then be obtained and compared to the $r$ values from the linear regression. The Pearson's $r$ values derived between the PMF factors and combustion tracers are shown in Table 1. Including both sources in this way significantly improves the correlations with the gas tracers for both sets of solutions. However, there is little difference between the regression fit $r$ values for the two solution sets with the 4-factor solution showing a very slightly greater correlation with $\mathrm{NO}_{\mathrm{x}}$ than the 5-factor solution. An additional multi-linear regression fit was performed with SFOA1 and SFOA2 as separate predictor variables, similar to the method used by Liu et al. (2014). The Pearson's $r$ values are shown in Table 1. The correlations for both $\mathrm{CO}$ and $\mathrm{NO}_{\mathrm{x}}$ are improved when the two factors are included as separate variables.

Overall there is little difference between the SFOA derived in the 4-factor solution and the combined factor from the 5-factor solution, so both could be valid solution sets. However, because the 5-factor solution with the two SFOA 
Table 1. Pearson's $r$ correlation coefficients for linear and multilinear regressions between PMF factors from the 4- and 5-factor solutions and combustion tracers.

\begin{tabular}{lcc}
\hline & $\mathrm{CO}$ & $\mathrm{NO}_{\mathrm{x}}$ \\
\hline SFOA-4fac & 0.56 & 0.43 \\
SFOA-combined & 0.65 & 0.51 \\
$f$ (HOA,SFOA)-4fac & 0.77 & 0.74 \\
$f$ (HOA,SFOA)-combined & 0.77 & 0.79 \\
$f$ (HOA, SFOA1, SFOA2) & 0.71 & 0.74 \\
\hline
\end{tabular}

factors combined gave improvements to diagnostics such as $Q / Q_{\text {expected }}$ (4.375 compared to 4.7764 for the 4 -factor solution) and correlations with ancillary data (see Sect. 5.1.4 in the Supplement for Young et al. (2014) for details), it was deemed that the 5-factor solution with the split SFOA factors was the most appropriate so is used in further analyses.

\subsection{Temporal variations and trends of the organic components}

The time series, average contributions to total organic mass, and diurnal profiles of all 5 factors identified from PMF analysis of the HR-ToF-AMS are shown in Fig. 1. The organic fraction is dominated by the POA components $(78 \%)$ with the remainder comprising OOA. The contributions of HOA, COA, SFOA1 and SFOA2 to the total organic mass are nearly equal $(19,21,18$ and $20 \%$, respectively). When combined, the SFOA factors represent the largest contribution to the organic fraction of NR-PM 1 in the winter in London.

The average ( \pm one standard deviation) HOA concentration during the winter was $0.83( \pm 1.37) \mu \mathrm{g} \mathrm{m}^{-3}$, with a maximum concentration of $24.5 \mu \mathrm{g} \mathrm{m}^{-3}$ measured on $16 \mathrm{Jan}$ uary. This is the largest HOA event as well as the greatest concentration measured for all factors during the winter measurement period. As HOA is related to traffic emissions, this event could be the result of a vehicle parked close to the site with its engine running. However, there is no record of a parked vehicle at this time, thus the event cannot be justifiably removed from the data set. The diurnal profile of HOA only exhibits one main peak in concentration at 10:00 UTC, although there is possibly a broad peak between 16:00 and 23:00 where concentrations are approximately two-thirds that of the morning peak. These peaks are associated with rush hours in London.

COA had a mean concentration of $0.88( \pm 1.73) \mu \mathrm{g} \mathrm{m}^{-3}$ and a peak in concentration of $18.3 \mu \mathrm{g} \mathrm{m}^{-3}$ on 14 January. COA exhibits the most pronounced diurnal profile of all the factors, with a peak in concentration between 20:00 and 22:00, and a smaller peak at 14:00, both associated with meal times. The timing of the evening peak is more likely associated with commercial activities than domestic meal times in the UK.
The average SFOA1 concentration was 0.75 $( \pm 0.98) \mu \mathrm{g} \mathrm{m}^{-3}$ with a maximum concentration of $8.0 \mu \mathrm{g} \mathrm{m}^{-3}$ measured on 17 January. SFOA1 exhibits a relatively smooth diurnal profile with greater concentrations during the night compared to the day. In contrast, the average concentration SFOA2 was $0.86( \pm 0.77) \mu \mathrm{g} \mathrm{m}^{-3}$ and peaked on 14 January, with a concentration of $5.2 \mu \mathrm{g} \mathrm{m}^{-3}$. The diurnal profile of SFOA2 is similar to SFOA1 with greater concentrations during the night, but SFOA2 also exhibits a small peak in concentrations between 10:00 and 11:00.

Finally, the mean concentration of OOA was 0.93 $( \pm 1.11) \mu \mathrm{g} \mathrm{m}^{-3}$ and peaked on 31 January with a concentration of $5.4 \mu \mathrm{g} \mathrm{m}^{-3}$. OOA does not exhibit a discernable diurnal pattern, which is consistent with it representing a regional, oxygenated aerosol.

\section{Investigating the SFOA factors}

In this paper, we investigate the behaviour of the solid fuel component of the organic fraction including the differences between the two SFOA factors from the HR-ToF-AMS for the winter IOP as well as the annual and seasonal trends of SFOA using the factors from the cToF-AMS. Details of the PMF analysis of both data sets are covered in a separate publication, where the annual behaviour of the secondary inorganic and organic aerosols is also investigated (Young et al., 2014).

Both SFOA1 and SFOA2 increase in concentration during the night (Fig. 1), as well as during the colder periods of the campaign (Fig. 2), which is consistent with them being associated with space heating activities. In addition to anthropogenic activities, there is reduced mixing in the boundary layer during the winter and therefore less dispersion, resulting in increased levels of aerosols. Other dynamical effects, such as episodic wintertime inversions, also play a role in driving changes in concentrations whereby local pollution is trapped resulting in a build-up of pollution (Martin et al., 2011). Such influences are evident during the winter of 2012 where the concentrations of all factors increase simultaneously in some events.

\subsection{Role of air mass history}

Advected pollution can also affect aerosol concentrations (e.g. Young et al., 2014). Liu et al. (2014) considered the influence of air mass history on BC concentrations in London during the winter including the influence of solid fuel burning sources in different air masses, as BC in their study is produced from combustion processes. Increases in BC mass were primarily coincident with easterly air masses. Here, the concentrations of the two SFOA factors were investigated as a function of wind speed and direction to determine whether different sources in terms of spatial locations are governing the split between the two factors. Polar plots are used to ex- 

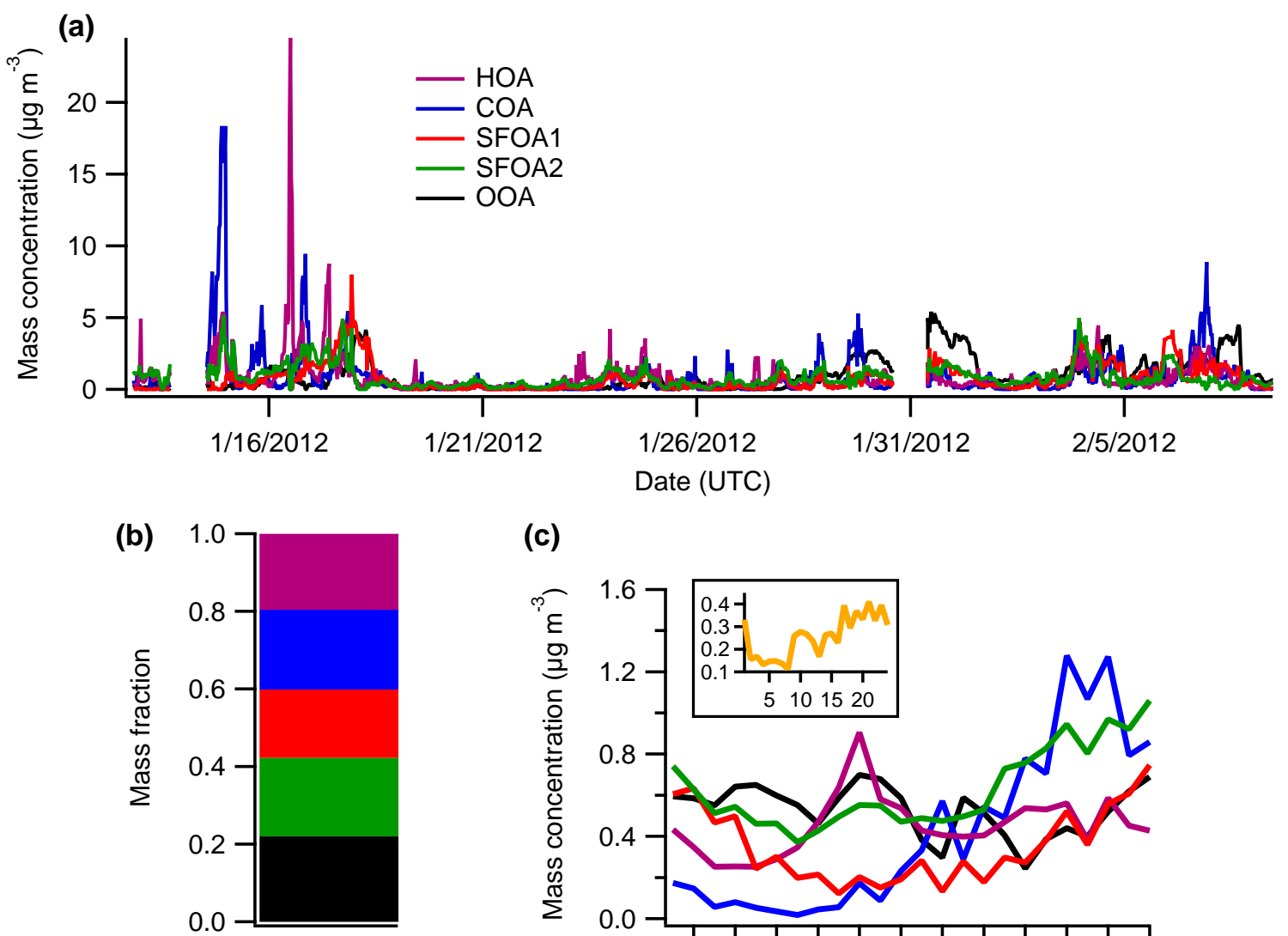

(c)

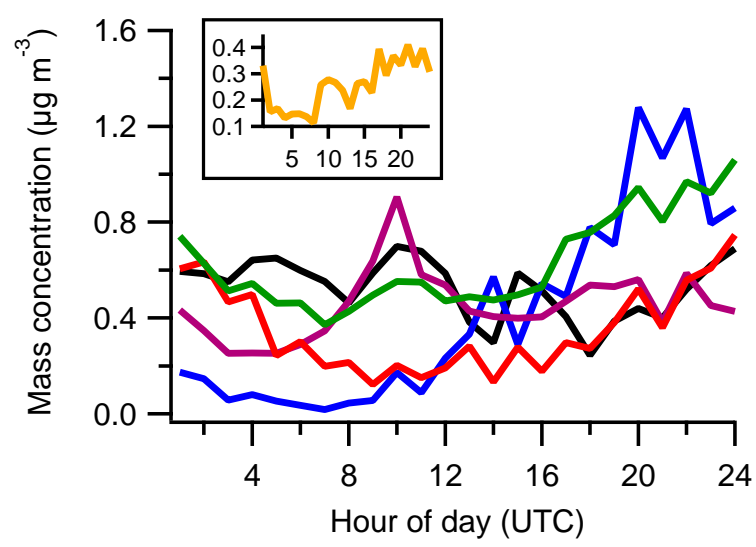

Figure 1. (a) Time series of the 5-factor-PMF solution from the HR-ToF-AMS. (b) Average fractional contribution to the total non-refractory submicron organic aerosol mass, where the residual accounts for $1.24 \%$ of the mass (also see Fig. S27 in Sect. 5.1.2 in the Supplement to Young et al. (2014), the complementary paper). (c) Median diurnal profiles for each of the five factors and the diurnal profile of the difference between the two SFOA factors (SFOA2-SFOA1, inset).

plore spatial differences in the concentrations of SFOA1 and SFOA2 and are shown in Fig. 3. The wind data used in these plots are from the meteorological station at Heathrow airport rather than local meteorological data as the latter are strongly influenced by surrounding buildings (e.g. Bigi and Harrison, 2010) and thus do not provide representative insight into spatial differences in the SFOA concentrations. The greatest SFOA1 concentrations are in the south, whereas the greatest SFOA2 concentrations are in the east and west and occur at slightly lower wind speeds compared to SFOA1.

\subsection{Investigating the behaviour of SFOA}

The composition of biomass burning and solid fuel OA, and therefore the mass spectra, are not constant (DeCarlo et al., 2010); they vary due to different combustion types, fuel types and levels of processing. This is consistent with changes in composition measured by various techniques (e.g. Schauer et al., 1996). Weimer et al. (2008) suggest that the mass spectral signature of wood burning is influenced more by the burning conditions than the fuel type. Crippa et al. (2014) also recommend that in factorisation analyses using the multilinear engine ME-2, mass spectra representative of typical burning conditions for a particular measurement site should be used if they are known. In this study, a combination of these variables may govern the split into the two SFOA factors, where several different fuel types may also be contributing to the two SFOA factors identified in this study, so they are classed more generally as solid fuel OA as opposed to biomass burning OA (BBOA).

The high variability of the SFOA mass spectral profile has been identified in many studies (Weimer et al., 2008; Grieshop, et al., 2009) including those where factor analysis and apportionment techniques have been applied (DeCarlo et al., 2010; Ng et al., 2011; Crippa et al., 2013, 2014). Some markers frequently used to identify biomass and solid fuel burning aerosols may not always be appropriate depending on the measurement conditions (DeCarlo et al., 2010; Hennigan et al., 2010) including ambient temperatures, duration 


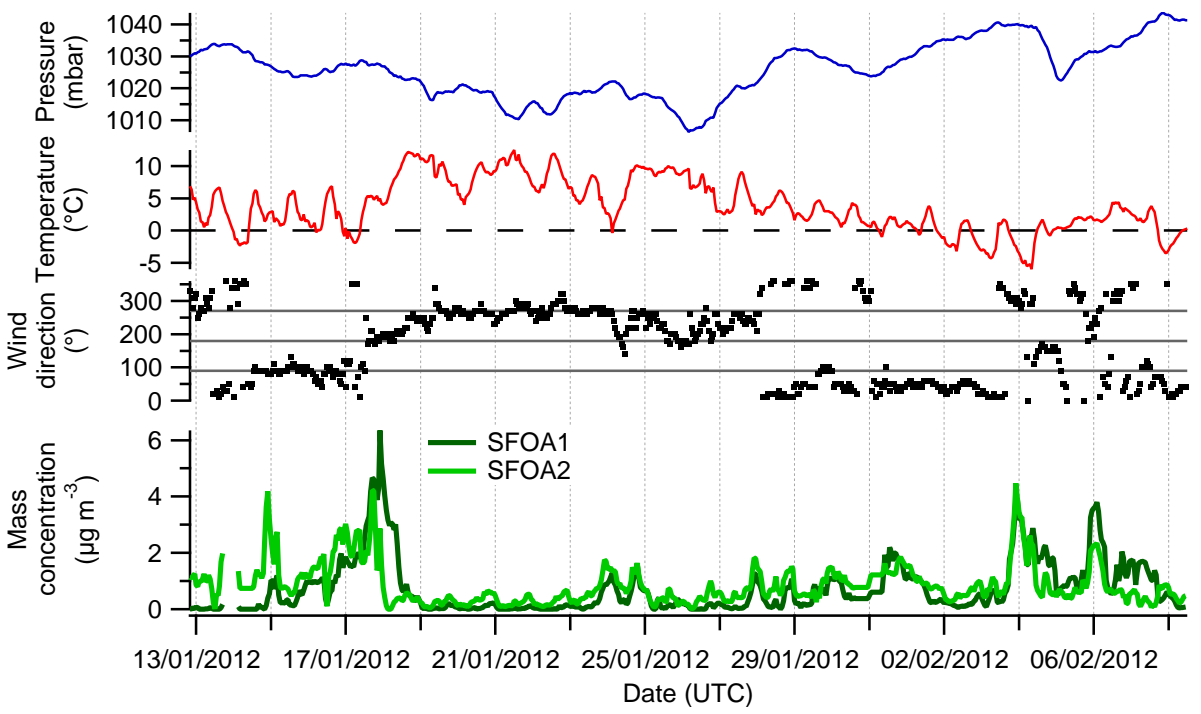

Figure 2. Time series of SFOA1 and SFOA2 concentration and meteorological data from the Heathrow airport meteorological station. The horizontal grid lines in the wind direction sub-plot, from top to bottom, represent westerly, southerly and easterly wind directions, respectively.
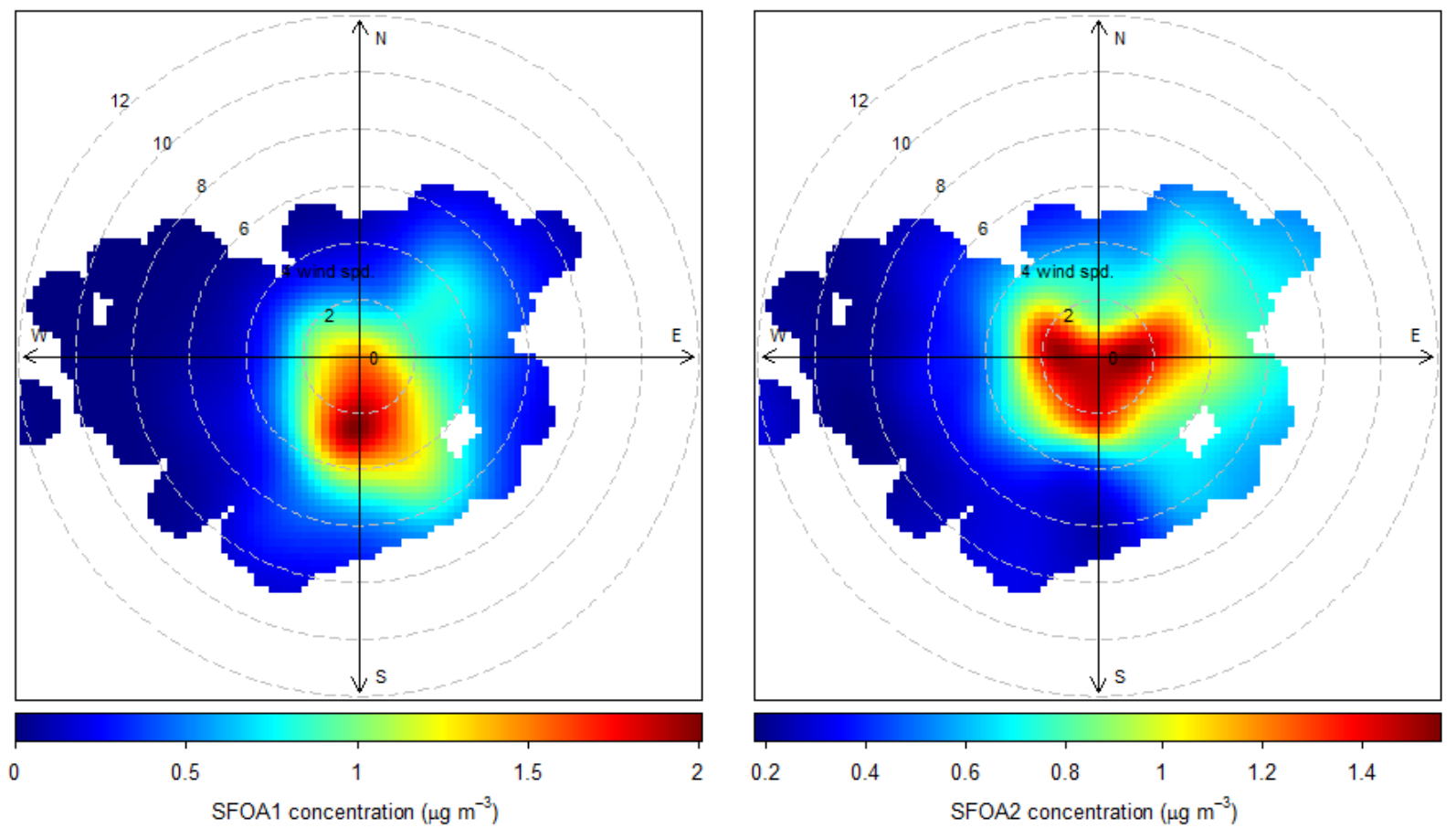

Figure 3. Polar plots of hourly averaged SFOA1 (left) and SFOA2 (right) concentrations as a function of wind speed and direction, where the wind data are from the Heathrow airport meteorological station, which are unaffected by large buildings. These polar plots were plotted in R using the openair package (Carslaw and Ropkins, 2012; Carslaw, 2013) which is a data analysis tool used to investigate air pollution.

of the measurements, and other sources of OA such as cooking (Mohr et al., 2009). Furthermore, BBOA evolves in the atmosphere through oxidation, whereby aged biomass burning aerosols have mass spectra similar to that of fulvic acid, used to represent highly oxidised OA with a large signal at $m / z 44$ (Capes et al., 2008; Grieshop et al., 2009; DeCarlo et al., 2010; Cubison et al, 2011; Lack et al., 2013). Consequently, it can sometimes be difficult to determine from the mass spectra and time series derived from PMF alone whether a factor represents primary SFOA, processed pri- 


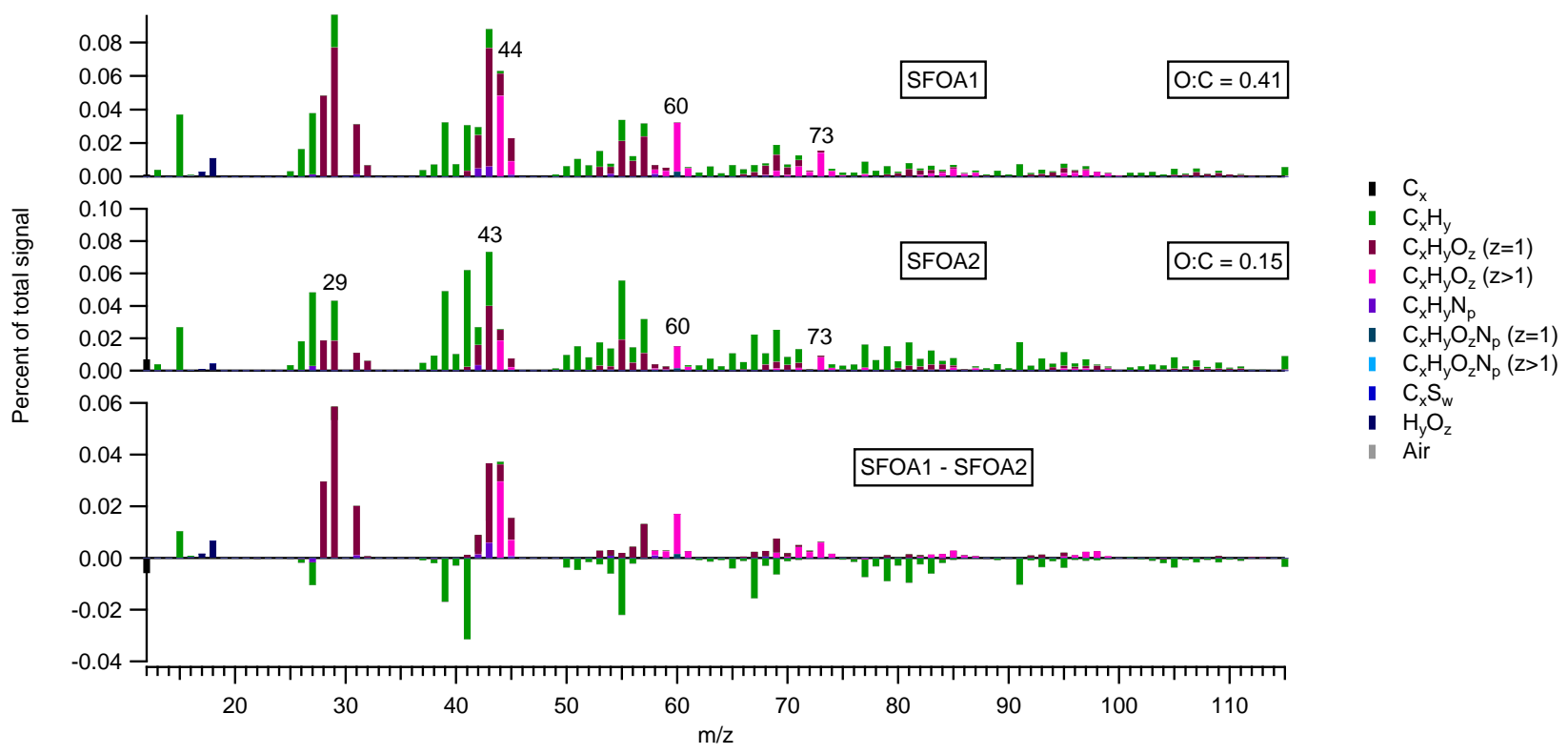

Figure 4. Mass spectra of SFOA1 (top) and SFOA2 (middle) as derived from PMF analysis of the HR-ToF-AMS organic data. Bottom: the difference between the mass spectral profiles of SFOA1 and SFOA2, where there are differences in the structure of the peaks above and below the line, compared to the individual MS of SFOA1 and SFOA2. For example, the peaks above the line are primarily composed of oxidised hydrocarbons at $m / z$ 's $43,44,57$ and 60 and the peaks below the line are primarily composed of reduced hydrocarbons. Prominent peaks in the SFOA1 MS such as $m / z$ 's 41 and 55 are not present above the line in the difference MS and peaks at $m / z$ 's 43 and 57 in the SFOA2 MS are not present below the line in the difference MS.

mary SFOA, SOA formed from SFOA, or a mixture of SFOA and OOA which are co-emitted (e.g. Crippa et al., 2013). Therefore, various metrics and graphical representations of the data are used in order to better interpret and characterise combustion related aerosols, where additional measurements support and improve interpretations.

In this study, the two SFOA factors are correlated in time (Fig. 2) whereby, although differing in magnitude, most of the high-concentration events for both factors occur during the same period, although not necessarily simultaneously such as on 17 January. The two factors are therefore linked but as the chemical profile changes with time the two factors represent the range of variability of SFOA composition. The two SFOA factors differ by way of diurnal variation (Fig. 1c inset) as well as chemical composition (Fig. 4). The mass spectra of SFOA1 and SFOA2 exhibit the typical peaks used as BBOA tracers at $m / z$ 's 60 and 73 (Alfarra et al., 2007) and compare very strongly with reference mass spectra (Pearson's $r$ of 0.94 and 0.88 , respectively; BBOA, $\mathrm{Ng}$ et al., 2011). Although both factors comprise several similar peaks, such as at $m / z$ 's $43\left(\mathrm{C}_{3} \mathrm{H}_{7}^{+}, \mathrm{C}_{2} \mathrm{H}_{3} \mathrm{O}^{+}\right), 55$ $\left(\mathrm{C}_{4} \mathrm{H}_{7}^{+}, \mathrm{C}_{3} \mathrm{H}_{3} \mathrm{O}^{+}\right), 57\left(\mathrm{C}_{4} \mathrm{H}_{9}^{+}, \mathrm{C}_{3} \mathrm{H}_{5} \mathrm{O}^{+}\right), 60\left(\mathrm{C}_{2} \mathrm{H}_{4} \mathrm{O}_{2}^{+}\right)$and $73\left(\mathrm{C}_{3} \mathrm{H}_{5} \mathrm{O}_{2}^{+}\right)$, SFOA1 also has a greater signal at $m / z 44$. Furthermore, SFOA1 also comprises more oxygenated compounds than SFOA2.

The difference in the mass spectra (MS) of the two factors highlights the variation within SFOA, which likely led to the derivation of a split factor by the PMF algorithm. The main chemical differences between the two factors are shown in the difference MS in Fig. 4, where the chemical groups appear to be affected differently by what is driving the split between the factors. Therefore, to better understand these differences the roles of atmospheric processing, fuel type and burn conditions, including burn phase, in varying the MS of SFOA and their influences in governing the split into two factors are investigated in the following sections.

\subsubsection{Role of atmospheric processing}

Analogous to OOA, the two SFOA factors derived from PMF analysis in this study may also represent end members of a continuum, where conditions during the winter enable the separation of SFOA into the two factors. The O: $\mathrm{C}$ ratio can be used to indicate the degree of oxygenation and level of processing the aerosols have undergone. Here, the $\mathrm{O}: \mathrm{C}$ ratio is based on the algorithms described in Aiken et al. (2007, 2008 ) and is 0.41 for SFOA 1 , whereas for SFOA2 it is 0.15 and 0.53 for OOA. This suggests that SFOA1 and SFOA2 differ by degree of oxygenation, which could hypothetically be a function of age, whereby SFOA1 is more processed than SFOA2. However, the type and phase of combustion can also affect the signal at $m / z$ 44. Increases in $f_{44}$ are typically found to coincide with decreases in $f_{60}$ (e.g. Cubison et al., 2011) (the ratio of the organic signal at $m / z 60$ to the total organic signal in the component mass spectrum) from oxidative decay of species such as levoglucosan. The $f_{60}$ vs. $f_{44}$ 
space (Cubison et al., 2011) is therefore used to characterise the evolution of biomass burning aerosols, with data from many studies exhibiting a negative correlation between $f_{44}$ and $f_{60}$ (Cubison et al., 2011; Ortega et al., 2013; Jolleys et al., 2014a). If the two SFOA factors represented different levels of processing of the same fuel type under similar conditions then SFOA1 would be expected to have higher $f_{44}$ and lower $f_{60}$ compared SFOA2. Figure 5 shows how the two SFOA factors map in the $f_{44}$ vs. $f_{60}$ space, with SFOA1 exhibiting higher $f_{60}$ as well as $f_{44}$ compared to SFOA1. From this, it can be inferred that the other factors such as differences in fuel types or burn conditions are also contributing to governing the split between the two factors rather than just differences in the degree of atmospheric processing.

\subsubsection{Role of fuel type}

In the latest National Atmospheric Emissions Inventory from 2011, wood was the largest contributor to $\mathrm{PM}_{1}$ emissions from domestic combustion activities in the UK $(51 \%$, NAEI, $2014)$, followed by coal $(31 \%)$ with only small contributions from natural gas $(9 \%)$ and peat $(2 \%)$. In a recent study in Cork, Ireland (Dall'Osto et al., 2013), a peat and coal OA factor was identified from PMF analysis of ambient data, with mass spectra of wood, peat and coal combustion obtained from laboratory experiments. However, due to the high variability of AMS mass spectra of biomass burning and solid fuel aerosols as mentioned previously, comparisons with other ancillary measurements and apportionment techniques are required to determine the role of fuel type on governing the split between the two SFOA factors.

Along with anhydrosugars such as levoglucosan and mannosan, chloride is used as a tracer for biomass burning (Dall'Osto et al., 2013) as well as for coal combustion (Sun et al., 2013); contributions of chloride from coal have been found to be greater than that from wood (Zhang et al., 2012). However, a comparison of the sum of the SFOA factors with potential sources from Chemical Mass Balance (CMB) modelling of filter samples revealed a greater correlation when the sum of wood smoke and coal from Yin et al. (2015) was considered rather than wood smoke alone (Yin et al., 2015). Moreover, the stronger correlation was achieved when the two SFOA factors were also summed suggesting that although several fuel types are contributing to SFOA, the split between the two factors is not solely driven by a difference in fuel type.

\subsubsection{Role of burn conditions}

Burn conditions can result in variations in the emissions from solid fuel burning, where such conditions include different burners or technologies and burn phase. Weimer et al. (2008) suggested that a low $m / z 44$ signal is indicative of the flaming phase whereas high signals occur during the smouldering phase. Contrastingly, Jolleys et al. (2014b) found in-

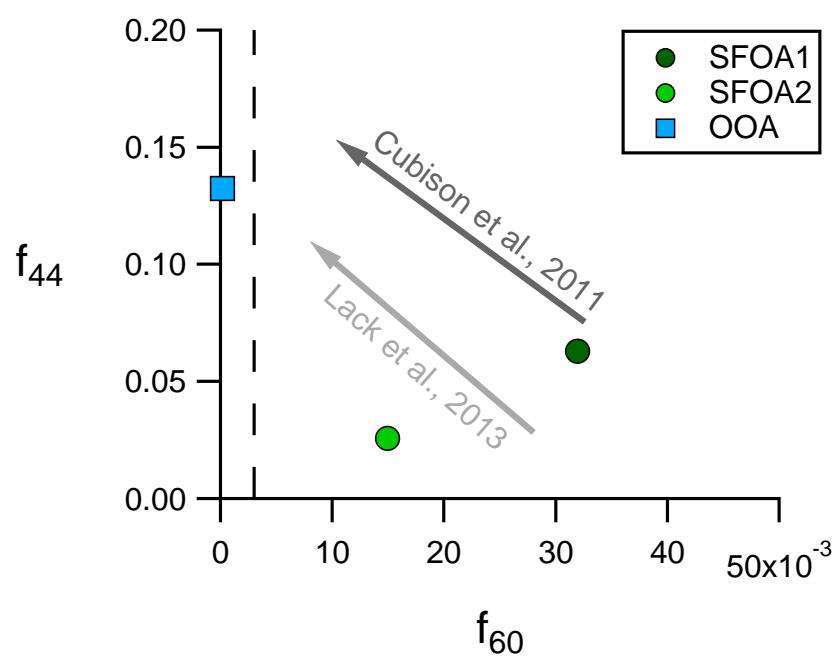

Figure 5. $f_{44}$ vs. $f_{60}$ for the SFOA1 and SFOA2 factors derived from PMF analysis of the HR-ToF-AMS organic data. OOA is also plotted for reference. The dashed line indicates the background $f_{60}$ level of $0.3 \%$ as defined by Cubison et al. (2011). The arrows indicate direction of aging observed in various plumes measured in Cubison et al. (2011, dark grey arrow) and Lack et al. (2013, light grey arrow).

creased $f_{44}$ occurred more frequently during flaming combustion than smouldering burns. These opposing conclusions highlight the dependency of emissions from fires on a variety of factors, including burn conditions and fuel type. Furthermore, different methods are used in these studies, resulting in very different mass spectra being obtained. This could be due to different fuel types, burner, or changes to the profile that occur between the source and the receptor, thus mass spectra are not necessarily directly comparable. Therefore additional information and various metrics have been used to better understand the influences from variations within each of these factors such as whether a burn is predominantly flaming or smouldering (Yokelson et al., 1996). Puxbaum et al. (2007) used the ratio of organic carbon to levoglucosan to determine the type of combustion, such as fires in small ovens and open wild fires. In this study, the ratio of SFOA1 to levoglucosan is 13.2, whereas for SFOA2 it is 10.1 , which are similar to the value obtained by Sciare et al. (2011) in Paris (10.3) for $\mathrm{PM}_{2.5}$ wood burning organic matter/levoglucosan. The similarity of the ratios of the two factors suggests that different phases of combustion may be occurring under similar conditions. This could mean that the same burner type is being used, for example, but the combustion phase is different, such as flaming or smouldering. However, levoglucosan is not completely stable in the atmosphere (Hennigan et al., 2010) so may not be a suitable tracer when used on its own.

Due to the sensitivity of wood smoke tracers to combustion conditions, Harrison et al. (2012a) used the levoglucosan : potassium ratio to evaluate wood smoke in the UK. Two potential sources of wood smoke were suggested: wood 


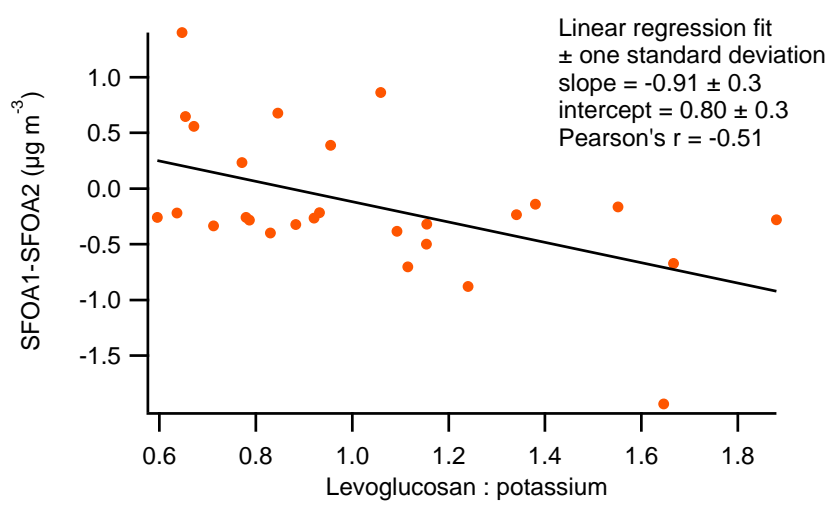

Figure 6. Variation of the difference between SFOA1 and SFOA2 concentrations with the levoglucosan: potassium ratio as derived from $24 \mathrm{~h}$ filter samples.

stoves/fireplaces, with a high ratio, and modern appliances, with a low ratio. Low-temperature flaming combustion results in a high organic content whereas a low ratio results from very high burn-out efficiency. In Fig. 6, the difference between the two SFOA factors is plotted against the levoglucosan : potassium ratio from $24 \mathrm{~h}$ filter samples from North Kensington. In general, higher SFOA1 concentrations are coincident with a lower levoglucosan: potassium ratio, whereas higher SFOA2 concentrations are coincident with a higher ratio. This could therefore suggest that SFOA1 represents a more efficient burn compared to SFOA2. Such conditions could be the result of efficient burner types, the use of well-seasoned wood, or represent the flaming phase of the burn. This is in keeping with the mass spectral profile of SFOA1 exhibiting a large signal at $m / z$ 44, indicative of fast combustion which results in the conversion of organic matter to $\mathrm{CO}_{2}(\mathrm{~g})$. The converse represents less efficient burn conditions, which is seen in the mass spectral profile of SFOA2. Furthermore, flaming combustion involves high temperatures, evident in the MS of SFOA1, which appears to favour greater functionalisation whereas SFOA2 is predominantly composed of aliphatic chains (Fig. 4). Similar to the findings of Weimer et al. (2008), levoglucosan signals in the MS of SFOA1 i.e. $m / z$ 's 60 and 73, are enhanced compared to those in the MS of SFOA2, suggesting that SFOA1 represents higher-temperature burns as it is expected that higher thermal breakdown occurs at higher temperatures in flaming combustion (Weimer et al., 2008). In summary, differences in burn efficiency are potentially governing the split between the two SFOA factors. Inventory data for the emissions from solid fuel combustion is of poor quality and other data such as regarding burner installations for example, are not available, thus the cause for differences in burn efficiency can only be speculated on.

\section{Contributions of SFOA to total NR-PM 1 and longer term temporal trends}

SFOA1 contributes $18 \%$ to the total organic fraction and SFOA2 contributes $20 \%$ (Fig. 1b), where the sum of both factors is similar to the contribution of the SFOA factor in Young et al. (2014) derived from PMF analysis of the organic matrix from the cToF-AMS (33\%) for the same period. The contribution of cToF-AMS SFOA to total organics during the whole winter season (January, February, December 2012 and January 2013) was $35 \%$. Since no SFOA factor was derived from PMF analysis of the summer HR-ToF-AMS data set, the long-term cToF-AMS data set described in Young et al. (2014) is used to investigate the seasonal trends of SFOA.

Only one SFOA factor was derived from PMF analysis of the cToF-AMS data, due to the lower mass resolution of this version of the instrument compared to the HR-ToF-AMS where different ions at the same nominal $\mathrm{m} / \mathrm{z}$ can be distinguished. The derivation of a single SFOA factor is also likely a result of the broad range of photochemical conditions and time that are covered by the year-long data set. If significantly aged, some SFOA may be apportioned to SOA (OOA) by PMF due to the chemical similarity. Furthermore, if SFOA has been aged or advected, $f_{60}$ may no longer be a reliable marker (Cubison et al., 2011). Heringa et al. (2011) also found that SOA significantly contributed to $m / z 60$ depending on the burning conditions. Nevertheless, SFOA contributes $18 \%$ to the total organic mass in spring, $11 \%$ in summer and $26 \%$ in autumn. This is consistent with the findings of Allan et al. (2010) for autumn 2007 as part of the REPARTEE experiment (Harrison et al., 2012b), which also took place in London, where SFOA was found to represent $26 \%$ of POA. This seasonality, where the contribution of SFOA to total organic mass as well as actual mass concentration increases during the autumn and winter, is consistent with domestic space heating activities.

As expected, temperatures were greater in the summer compared to the winter, which is why solid fuel aerosols were not discernable from the HR-ToF-AMS data set from the summer IOP. However, as SFOA is still found to contribute to the total organic mass during this period it could be that this factor represents a different activity to domestic space heating during the winter. Gardening waste and forest wood burning occurs in the summer, with wood and other fuel types burned for barbecues (Crippa et al., 2014; Lanz et al., 2007).

\section{Conclusions}

An investigation into the differences between two SFOA factors derived from PMF analysis of the organic fraction of NR-PM ${ }_{1}$ as measured by the HR-ToF-AMS in London during winter 2012 is presented. Spatial differences in the concentrations of both SFOA factors were found where SFOA1 
had influences from the south whereas SFOA2 had influences from the east and west. However, the reason for these different spatial influences is not known. The chemical profile of SFOA is known to vary due to differences in fuel type, the degree of atmospheric processing and burn conditions; various methods were therefore used to distinguish between the two factors on the process level and determine the importance of each of these variables in governing the split.

SFOA1 was found to be more oxygenated organic matter than SFOA2; however, correlations with ancillary data suggested that the split in SFOA was not likely to be primarily driven by differences in fuel type or degree of processing. The ratio of the biomass burning tracers, levoglucosan and potassium, was used to identify the importance of different burn conditions in controlling the split between the two SFOA factors. Higher SFOA1 than SFOA2 concentrations were coincident with a low ratio, indicating that SFOA1 likely represents a high-efficiency burn whereas SFOA2 likely represents less efficient burn conditions such as the smouldering phase of a burn. Therefore, each of the SFOA factors represents different conditions where burn conditions can include the burner type/technology, whether fireplace or modern appliances, burn phase, smouldering or flaming, and time since the fire was lit. As diagnostics in both PMF and CMB analyses improved by considering both SFOA factors and the differences between the two factors are identifiable on a chemical basis, there are implications for future source apportionment analyses and interpretation of other data. It is possible that the uncertainty surrounding SFOA in PMF and multilinear engine ME-2 analyses (Canonaco et al., 2013) could be addressed by including two factors which better characterise the variability of solid fuel burning aerosols by improving the accuracy and reducing the rotational ambiguity in such analyses.

Increases in the concentrations of both SFOA factors are consistent with their association with space heating activities. During the winter, SFOA1 contributed $18 \%$ to the total organic mass whereas SFOA2 contributed $20 \%$, where the sum of the two factors is comparable to the contribution of the single SFOA factor identified from the cToF-AMS data set. The seasonality of SFOA was investigated using the long-term data set where SFOA contributed $18 \%$ to the total organic mass in spring, $11 \%$ in summer and $26 \%$ in autumn. The presence of SFOA during the summer could be due to activities such as barbecuing, as well as domestic garden and forest wood burning. This study highlights the importance of SFOA where it is evident that wood burning and other solid fuel burning activities are occurring in London despite the implementation of various legislative measures. Changes in the economy, including increases in fossil fuel prices, may lead to an increase in the contribution of SFOA to the total NR-PM 1 aerosol burden, which could have significant influences in forming future air quality policies and mitigation strategies due to the associations between fine combustion aerosols and adverse health, air quality, and climate effects.
As the use of renewable energy sources is also set to increase across the European Union, it may be expected that similar conclusions are reached in other countries with comparably significant implications for policies and pollution abatement.

\section{Data availability}

Processed data are available through the ClearfLo project archive at the British Atmospheric Data Centre (http://badc. nerc.ac.uk/browse/badc/clearflo). Raw data are archived at the University of Manchester and are available on request.

Acknowledgements. This work was supported in part by the UK Natural Environment Research Council (NERC) ClearfLo project (grant ref. NE/H008136/1) and is coordinated by the National Centre for Atmospheric Science (NCAS). Additional support for the aerosol measurements was provided by the Department of Environment, Food and Rural Affairs (DEFRA). D. E. Young was supported by a NERC PhD studentship (ref. NE/I528142/1). The authors would like to thank James Lee from NCAS at the University of York for the $\mathrm{CO}, \mathrm{NO}$ and $\mathrm{NO}_{2}$ data as well as for logistical assistance at the North Kensington supersite during the IOPs. The authors would also like to thank Anja Tremper at King's College London for assisting with instrument maintenance. Additional thanks to the Sion Manning School in North Kensington and adjacent community centre.

Edited by: A. Huffman

\section{References}

Aiken, A. C., DeCarlo, P. F., and Jimenez, J. L.: Elemental analysis of organic species with electron ionization highresolution mass spectrometry, Anal. Chem., 79, 8350-8358, doi:10.1021/ac071150w, 2007.

Aiken, A. C., DeCarlo, P. F., Kroll, J. H., Worsnop, D. R., Huffman, J. A., Docherty, K. S., Ulbrich, I. M., Mohr, C., Kimmel, J. R., Sueper, D., Sun, Y., Zhang, Q., Trimborn, A., Northway, M., Ziemann, P. J., Canagaratna, M. R., Onasch, T. B., Alfarra, M. R., Prevot, A. S. H., Dommen, J., Duplissy, J., Metzger, A., Baltensperger, U., and Jimenez, J. L.: O/C and OM/OC ratios of primary, secondary, and ambient organic aerosols with high-resolution time-of-flight aerosol mass spectrometry, Environ. Sci. Technol., 42, 4478-4485, 2008.

Alfarra, M. R., Prevot, A. S. H., Szidat, S., Sandradewi, J., Weimer, S., Lanz, V. A., Schreiber, D., Mohr, M., and Baltensperger, U.: Identification of the mass spectral signature of organic aerosols from wood burning emissions, Environ. Sci. Technol., 41, 57705777, 2007.

Allan, J. D., Williams, P. I., Morgan, W. T., Martin, C. L., Flynn, M. J., Lee, J., Nemitz, E., Phillips, G. J., Gallagher, M. W., and Coe, H.: Contributions from transport, solid fuel burning and cooking to primary organic aerosols in two UK cities, Atmos. Chem. Phys., 10, 647-668, doi:10.5194/acp-10-647-2010, 2010. 
Bigi, A. and Harrison, R. M.: Analysis of the air pollution climate at a central urban background site, Atmos. Environ., 44, 2004 2012, 2010.

Bohnenstengel, S. I., Belcher, S. E., Aiken, A. C., Allan, J. D., Allen, G., Bacak, A., Bannan, T. J., Barlow, J. F., Beddows, D. C. S., Bloss, W. J., Booth, A. M., Chemel, C., Coceal, O., Di Marco, C. F., Dubey, M. K., Faloon, K. H., Fleming, Z., Furger, M., Geitl, J. K., Graves, R. R., Green, D. C., Grimmond, C. S. B., Halios, C., Hamilton, J. F., Harrison, R. M., Heal, M. R., Heard, D. E., Helfter, C., Herndon, S. C., Holmes, R. E., Hopkins, J. R., Jones, A. M., Kelly, F. J., Kotthaus, S., Langford, B., Lee, J. D., Leigh, R. J., Lewis, A. C., Lidster, R. T., Lopez-Hilfiker, F. D., McQuaid, J. B., Mohr, C., Monks, P. S., Nemitz, E., Ng, N. L., Percival, C. J., Prévôt, A. S. H., Ricketts, H. M. A., Sokhi, R., Stone, D., Thornton, J. A., Tremper, A. H., Valach, A. C., Visser, S., Whalley, L. K., Williams, L. R., Xu, L., Young, D. E., and Zotter, P.: Meteorology, air quality and health in London: the ClearfLo project, B. Am. Meteorol. Soc., doi:10.1175/BAMS-D12-00245.1, in press, 2015.

Bølling, A. K., Pagels, J., Yttri, K. E., Barregard, L., Sallsten, G., Schwarze, P. E., and Boman, C.: Health effects of residential wood smoke particles: the importance of combustion conditions and physicochemical particle properties, Part. Fibre Toxicol., 6:29, doi:10.1186/1743-8977-6-29, 2009.

Bond, T. C., Streets, D. G., Yarber, K. F., Nelson, S. M., Woo, J.-H., and Klimont, Z.: A technology-based global inventory of Black and Organic Carbon emissions from Combustion, J. Geophys. Res., 109, D14203, doi:10.1029/2003JD003697, 2004.

Borrego, C., Valente, J., Carvalho, A., Sá, E., Lopes, E., and Miranda, A. I.: Contribution of residential wood combustion to $\mathrm{PM}_{10}$ levels in Portugal, Atmos. Environ., 44, 642-651, 2010.

Canagaratna, M. R., Jayne, J. T., Jimenez, J. L., Allan, J. D., Alfarra, M. R., Zhang, Q., Onasch, T. B., Drewnick, F., Coe, H., Middlebrook, A., Delia, A. E., Williams, L. R., Trimborn, A. M., Northway, M. J., Decarlo, P. F., Kolb, C. E., Davidovits, P., and Worsnop, D. R.: Chemical and microphysical characterization of ambient aerosols with the aerodyne aerosol mass spectrometer, Mass Spectrom. Rev., 26, 185-222, doi:10.1002/mas.20115, 2007.

Canonaco, F., Crippa, M., Slowik, J. G., Baltensperger, U., and Prévôt, A. S. H.: SoFi, an IGOR-based interface for the efficient use of the generalized multilinear engine (ME-2) for the source apportionment: ME-2 application to aerosol mass spectrometer data, Atmos. Meas. Tech., 6, 3649-3661, doi:10.5194/amt6-3649-2013, 2013.

Capes, G., Johnson, B., McFiggans, G., Williams, P. I., Haywood, J., and Coe, H.: Aging of biomass burning aerosols over West Africa: Aircraft measurements of chemical composition, microphysical properties, and emission ratios, J. Geophys. Res., 113, D00C15, doi:10.1029/2008jd009845, 2008.

Carslaw, D. C.: The openair manual - open-source tools for analysing air pollution data, King's College London, 2013.

Carslaw, D. C. and K. Ropkins; openair - an R package for air quality data analysis, Environ. Model. Softw., 27-28, 52-61, 2012.

Caseiro, A., Bauer, H., Schmidl, C., Pio, C. A., and Puxbaum, H.: Wood burning impact on $\mathrm{PM}_{10}$ in three Austrian regions, Atmos. Environ, 43, 2186-2195, 2009.

Crilley, L. R., Bloss, W. J., Yin, J., Beddows, D. C. S., Harrison, R. M., Allan, J. D., Young, D. E., Flynn, M., Williams, P., Zot- ter, P., H. Prevot, A. S., Heal, M. R., Barlow, J. F., Halios, C. H., Lee, J. D., Szidat, S., and Mohr, C.: Sources and contributions of wood smoke during winter in London: assessing local and regional influences, Atmos. Chem. Phys. Discuss., 14, 27459 27530, doi:10.5194/acpd-14-27459-2014, 2014.

Crippa, M., DeCarlo, P. F., Slowik, J. G., Mohr, C., Heringa, M. F., Chirico, R., Poulain, L., Freutel, F., Sciare, J., Cozic, J., Di Marco, C. F., Elsasser, M., Nicolas, J. B., Marchand, N., Abidi, E., Wiedensohler, A., Drewnick, F., Schneider, J., Borrmann, S., Nemitz, E., Zimmermann, R., Jaffrezo, J.-L., Prévôt, A. S. H., and Baltensperger, U.: Wintertime aerosol chemical composition and source apportionment of the organic fraction in the metropolitan area of Paris, Atmos. Chem. Phys., 13, 961-981, doi:10.5194/acp-13-961-2013, 2013.

Crippa, M., Canonaco, F., Lanz, V. A., Äijälä, M., Allan, J. D., Carbone, S., Capes, G., Ceburnis, D., Dall'Osto, M., Day, D. A., DeCarlo, P. F., Ehn, M., Eriksson, A., Freney, E., Hildebrandt Ruiz, L., Hillamo, R., Jimenez, J. L., Junninen, H., Kiendler-Scharr, A., Kortelainen, A.-M., Kulmala, M., Laaksonen, A., Mensah, A. A., Mohr, C., Nemitz, E., O’Dowd, C., Ovadnevaite, J., Pandis, S. N., Petäjä, T., Poulain, L., Saarikoski, S., Sellegri, K., Swietlicki, E., Tiitta, P., Worsnop, D. R., Baltensperger, U., and Prévôt, A. S. H.: Organic aerosol components derived from 25 AMS data sets across Europe using a consistent ME-2 based source apportionment approach, Atmos. Chem. Phys., 14, 61596176, doi:10.5194/acp-14-6159-2014, 2014.

Cubison, M. J., Ortega, A. M., Hayes, P. L., Farmer, D. K., Day, D., Lechner, M. J., Brune, W. H., Apel, E., Diskin, G. S., Fisher, J. A., Fuelberg, H. E., Hecobian, A., Knapp, D. J., Mikoviny, T., Riemer, D., Sachse, G. W., Sessions, W., Weber, R. J., Weinheimer, A. J., Wisthaler, A., and Jimenez, J. L.: Effects of aging on organic aerosol from open biomass burning smoke in aircraft and laboratory studies, Atmos. Chem. Phys., 11, 12049-12064, doi:10.5194/acp-11-12049-2011, 2011.

Dall'Osto, M., Ovadnevaite, J., Ceburnis, D., Martin, D., Healy, R. M., O'Connor, I. P., Kourtchev, I., Sodeau, J. R., Wenger, J. C., and O'Dowd, C.: Characterization of urban aerosol in Cork city (Ireland) using aerosol mass spectrometry, Atmos. Chem. Phys., 13, 4997-5015, doi:10.5194/acp-13-4997-2013, 2013.

DeCarlo, P. F., Kimmel, J. R., Trimborn, A., Northway, M. J., Jayne, J. T., Aiken, A. C., Gonin, M., Fuhrer, K., Horvath, T., Docherty, K. S., Worsnop, D. R., and Jimenez, J. L.: Field-deployable, high-resolution, time-of-flight aerosol mass spectrometer, Anal. Chem., 78, 8281-8289, doi:10.1021/ac061249n, 2006.

DeCarlo, P. F., Ulbrich, I. M., Crounse, J., de Foy, B., Dunlea, E. J., Aiken, A. C., Knapp, D., Weinheimer, A. J., Campos, T., Wennberg, P. O., and Jimenez, J. L.: Investigation of the sources and processing of organic aerosol over the Central Mexican Plateau from aircraft measurements during MILAGRO, Atmos. Chem. Phys., 10, 5257-5280, doi:10.5194/acp-10-52572010, 2010.

Department for Environment: Food and Rural Affairs (Defra), UK Smoke Control Areas, avialable at: http://smokecontrol.defra. gov.uk/, last access: 26 March 2014.

Donaldson, K., Stone, V., Borm, P. J., Jimenez, L. A., Gilmour, P. S., Schins, R. P., Knaapen, A. M., Rhaman, I., Faux, S. P., Brown, D. M., and MacNee, W.: Oxidative stress and calcium signaling in the adverse effects of environmental particles $\left(\mathrm{PM}_{10}\right)$, Free Radical Bio. Med., 34, 1369-1382, 2003. 
Drewnick, F., Hings, S. S., Decarlo, P. F., Jayne, J. T., Gonin, M., Fuhrer, K.,Weimer, S., Jimenez, J. L., Demerjian, K. L., Borrmann, S., and Worsnop, D. R.: A new time-of-flight aerosol mass spectrometer (TOF-AMS) - Instrument description and first field deployment, Aerosol Sci. Tech., 39, 637-658, doi:10.1080/02786820500182040, 2005.

European Union: Directive 2008/50/EC of the European parliament and of the council of 21 May 2008 on ambient air quality and cleaner air for Europe, Official Journal of the European Union, L152, 2008

Fuller, G. W., Sciare, J., Lutz, M., Moukhtar, S., and Wagener, S.: New Directions: Time to tackle urban wood burning?, Atmos. Environ., 68, 295-296, doi:10.1016/j.atmosenv.2012.11.045, 2013.

Fuller, G. W., Tremper, A. H., Baker, T. D., Yttri, K. E., and Butterfield, D.: Contribution of wood burning to $\mathrm{PM}_{10}$ in London, Atmos. Environ., 87, 87-94, doi:10.1016/j.atmosenv.2013.12.037, 2014.

Glasius, M., Ketzel, M., Wahlin, P., Jensen, B., Monster, J., Berkowicz, R., and Palmgren, F.: Impact of wood combustion on particle levels in a residential area in Denmark, Atmos. Environ., 40, 7115-7124, doi:10.1016/j.atmosenv.2006.06.047, 2006.

Grieshop, A. P., Donahue, N. M., and Robinson, A. L.: Laboratory investigation of photochemical oxidation of organic aerosol from wood fires 2: analysis of aerosol mass spectrometer data, Atmos. Chem. Phys., 9, 2227-2240, doi:10.5194/acp-9-2227-2009, 2009.

Harrison, R. M., Beddows, D. C. S., Hu, L., and Yin, J.: Comparison of methods for evaluation of wood smoke and estimation of UK ambient concentrations, Atmos. Chem. Phys., 12, 82718283, doi:10.5194/acp-12-8271-2012, 2012a.

Harrison, R. M., Dall'Osto, M., Beddows, D. C. S., Thorpe, A. J., Bloss, W. J., Allan, J. D., Coe, H., Dorsey, J. R., Gallagher, M., Martin, C., Whitehead, J., Williams, P. I., Jones, R. L., Langridge, J. M., Benton, A. K., Ball, S. M., Langford, B., Hewitt, C. N., Davison, B., Martin, D., Petersson, K. F., Henshaw, S. J., White, I. R., Shallcross, D. E., Barlow, J. F., Dunbar, T., Davies, F., Nemitz, E., Phillips, G. J., Helfter, C., Di Marco, C. F., and Smith, S.: Atmospheric chemistry and physics in the atmosphere of a developed megacity (London): an overview of the REPARTEE experiment and its conclusions, Atmos. Chem. Phys., 12, 3065-3114, doi:10.5194/acp-12-3065-2012, 2012b.

Hellén, H., Hakola, H., Haaparanta, S., Pietarila, H., and Kauhaniemi, M.: Influence of residential wood combustion on local air quality, Sci. Total Environ., 393, 283-290, 2008.

Hennigan, C. J., Sullivan, A. P., Collett, J. L., and Robinson, A. L.: Levoglucosan stability in biomass burning particles exposed to hydroxyl radicals, Geophys. Res. Lett., 37, L09806, doi:10.1029/2010GL043088, 2010.

Heringa, M. F., DeCarlo, P. F., Chirico, R., Tritscher, T., Dommen, J., Weingartner, E., Richter, R., Wehrle, G., Prévôt, A. S. H., and Baltensperger, U.: Investigations of primary and secondary particulate matter of different wood combustion appliances with a high-resolution time-of-flight aerosol mass spectrometer, Atmos. Chem. Phys., 11, 5945-5957, doi:10.5194/acp-11-59452011, 2011

Huffman, J. A., Ziemann, P. J., Jayne, J. T., Worsnop, D. R., and Jimenez, J. L.: Development and Characterization of a FastStepping/Scanning Thermodenuder for Chemically-Resolved
Aerosol Volatility Measurements, Aerosol Sci. Tech., 42, 395407, 2008.

Jimenez, J. L., Canagaratna, M. R., Donahue, N. M., Prevot, A. S. H., Zhang, Q., Kroll, J. H., Decarlo, P. F., Allan, J. D., Coe, H., Ng, N. L., Aiken, A. C., Docherty, K. S., Ulbrich, I. M., Grieshop, A. P., Robinson, A. L., Duplissy, J., Smith, J. D., Wilson, K. R., Lanz, V. A., Hueglin, C., Sun, Y. L., Tian, J., Laaksonen, A., Raatikainen, T., Rautiainen, J., Vaattovaara, P., Ehn, M., Kulmala, M., Tomlinson, J. M., Collins, D. R., Cubison, M. J., E., Dunlea, E. J., Huffman, J. A., Onasch, T. B., Alfarra, M. R., Williams, P. I., Bower, K. N., Kondo, Y., Schneider, J., Drewnick, F., Borrmann, S., Weimer, S., Demerjian, K. L., Salcedo, D., Cottrell, L., Griffin, R., Takami, A., Miyoshi, T., Hatakeyama, S., Shimono, A., Sun, J. Y., Zhang, Y. M., Dzepina, K., Kimmel, J. R., Sueper, D., Jayne, J. T., Herndon, S. C., Trimborn, A. M.,Williams, L. R., Wood, E. C., Middlebrook, A. M., Kolb, C. E., Baltensperger, U., and Worsnop, D. R.: Evolution of Organic Aerosols in the Atmosphere, Science, 326, 1525-1529, doi:10.1126/science.1180353, 2009.

Jolleys, M. D., Coe, H., McFiggans, G., Taylor, J. W., O'Shea, S. J., Le Breton, M., Bauguitte, S. J.-B., Moller, S., Di Carlo, P., Aruffo, E., Palmer, P. I., and Lee, J. D.: Properties and evolution of biomass burning organic aerosol from Canadian boreal forest fires, Atmos. Chem. Phys. Discuss., 14, 25095-25138, doi:10.5194/acpd-14-25095-2014, 2014a.

Jolleys, M. D., Coe, H., McFiggans, G., McMeeking, G. R., Lee, T., Kreidnweis, S. M., Collett, J. L., and Sullivan, A. P.: Organic aerosol emission ratios from the laboratory combustion of biomass fuels, J. Geophys. Res.-Atmos., 119, 12850-12871, doi:10.1002/2014JD021589, 2014b.

Kanakidou, M., Seinfeld, J. H., Pandis, S. N., Barnes, I., Dentener, F. J., Facchini, M. C., Van Dingenen, R., Ervens, B., Nenes, A., Nielsen, C. J., Swietlicki, E., Putaud, J. P., Balkanski, Y., Fuzzi, S., Horth, J., Moortgat, G. K., Winterhalter, R., Myhre, C. E. L., Tsigaridis, K., Vignati, E., Stephanou, E. G., and Wilson, J.: Organic aerosol and global climate modelling: a review, Atmos. Chem. Phys., 5, 1053-1123, doi:10.5194/acp-5-1053-2005, 2005.

Lack, D. A., Bahreini, R., Langridge, J. M., Gilman, J. B., and Middlebrook, A. M.: Brown carbon absorption linked to organic mass tracers in biomass burning particles, Atmos. Chem. Phys., 13, 2415-2422, doi:10.5194/acp-13-2415-2013, 2013.

Lanz, V. A., Alfarra, M. R., Baltensperger, U., Buchmann, B., Hueglin, C., and Prévôt, A. S. H.: Source apportionment of submicron organic aerosols at an urban site by factor analytical modelling of aerosol mass spectra, Atmos. Chem. Phys., 7, 15031522, doi:10.5194/acp-7-1503-2007, 2007.

Liu, D., Allan, J. D., Young, D. E., Coe, H., Beddows, D., Fleming, Z. L., Flynn, M. J., Gallagher, M. W., Harrison, R. M., Lee, J., Prevot, A. S. H., Taylor, J. W., Yin, J., Williams, P. I., and Zotter, P.: Size distribution, mixing state and source apportionment of black carbon aerosol in London during wintertime, Atmos. Chem. Phys., 14, 10061-10084, doi:10.5194/acp14-10061-2014, 2014.

Martin, C. L., Allan, J. D., Crosier, J., Choularton, T. W., Coe, H., and Gallagher, M. W.: Seasonal variation of fine particulate composition in the centre of a UK city, Atmos. Environ., 45, 43794389, doi:10.1016/j.atmosenv.2011.05.050, 2011. 
Maykut, N. N., Lewtas, J., Kim, E., and Larson, T. V.: Source apportionment of $\mathrm{PM}_{2.5}$ at an urban IMPROVE site in Seattle, Washington, Environ. Sci. Technol., 37, 5135-5142, doi:10.1021/es030370y, 2003.

Mohr, C., Huffman, J. A., Cubison, M. J., Aiken, A. C., Docherty, K. S., Kimmel, J. R., Ulbrich, I. M., Hannigan, M., Garcia, J., and Jimenez, J. L.: Characterization of Primary Organic Aerosol Emissions from Meat Cooking, Trash Burning, and Motor Vehicles with High-Resolution Aerosol Mass Spectrometry and Comparison with Ambient and Chamber Observations, Environ. Sci. Technol., 43, 2443-2449, doi:10.1021/es8011518, 2009.

Mohr, C., DeCarlo, P. F., Heringa, M. F., Chirico, R., Slowik, J. G., Richter, R., Reche, C., Alastuey, A., Querol, X., Seco, R., Peñuelas, J., Jiménez, J. L., Crippa, M., Zimmermann, R., Baltensperger, U., and Prévôt, A. S. H.: Identification and quantification of organic aerosol from cooking and other sources in Barcelona using aerosol mass spectrometer data, Atmos. Chem. Phys., 12, 1649-1665, doi:10.5194/acp-12-1649-2012, 2012.

Mohr, C., Lopez-Hilfiker, F. D., Zotter, P., Prevot, A. S. H., Xu, L., Ng, N. L., Herndon, S. C., Williams, L. R., Franklin, J. P., Zahniser, M. S., Worsnop, D. R., Knighton, W. B., Aiken, A. C., Gorkowski, K. J., Dubey, M. K., Allan, J. D., and Thornton, J. A.: Contribution of nitrated phenols to wood burning brown carbon light absorption in Delting, United Kingdom during winter time, Environ. Sci. Technol., 47, 6316-6324, doi:10.1021/es400683v, 2013.

National atmospheric emissions inventory (NAEI): http://naei. defra.gov.uk/ (last access: 1 April 2014), 2014.

Ng, N. L., Canagaratna, M. R., Zhang, Q., Jimenez, J. L., Tian, J., Ulbrich, I. M., Kroll, J. H., Docherty, K. S., Chhabra, P. S., Bahreini, R., Murphy, S. M., Seinfeld, J. H., Hildebrandt, L., Donahue, N. M., DeCarlo, P. F., Lanz, V. A., Prévôt, A. S. H., Dinar, E., Rudich, Y., and Worsnop, D. R.: Organic aerosol components observed in Northern Hemispheric datasets from Aerosol Mass Spectrometry, Atmos. Chem. Phys., 10, 46254641, doi:10.5194/acp-10-4625-2010, 2010.

Ng, N., Canagaratna, M., Jimenez, J., Zhang, Q., Ulbricht, I., and Worsnop, D.: Real-time methods for estimating organics component mass concentrations from Aerosol Mass Spectrometry data, Environ. Sci. Technol., 45, 910-916, 2011.

Oberdörster, G., Oberdörster, E., and Oberdörster, J.: Nanotoxicology: An emerging discipline evolving from studies of ultrafine particles, Environ. Health Persp., 113, 823-839, 2005.

Ortega, A. M., Day, D. A., Cubison, M. J., Brune, W. H., Bon, D., de Gouw, J. A., and Jimenez, J. L.: Secondary organic aerosol formation and primary organic aerosol oxidation from biomass-burning smoke in a flow reactor during FLAME-3, Atmos. Chem. Phys., 13, 11551-11571, doi:10.5194/acp-1311551-2013, 2013.

Peabody, J. W., Riddell, T. J., Smith, K. R., Liu, Y., Zhao, Y., Gong, J., Milet, M., and Sinton, J. E.: Indoor Air Pollution in Rural China: Cooking Fuels, Stoves, and Health Status, Arch. Environ. Occup. H., 60, 86-95, 2005.

Pope III, C. A. and Dockery, D. W.: Health effects of fine particulate air pollution: lines that connect, J. Air Waste Manage., 56, 709742, doi:10.1080/10473289.2006.10464485, 2006.

Puxbaum, H., Caseiro, A., Sánchez-Ochos, A., Kasper-Giebl, A., Claeys, M., Gelencser, A., Legrand, M., Preunkert, S., and Pio, C.: Levoglucosan levels at background sites in Europe for assessing the impact of biomass combustion on the European aerosol background, J. Geophys. Res., 112, D23S05, doi:10.1029/2006JD008114, 2007.

Ries, F., Marshall, J. D., and Brauer, M.: Intake fraction of urban wood smoke, Environ. Sci. Technol., 43, 4701-4706, doi:10.1021/es803127d, 2009.

Schauer, J. J., Rogge, W. F., Hildemann, L. M., Mazurek, M. A., and Cass, G. R.: Source apportionment of airborne particulate matter using organic compounds as tracers, Atmos. Environ., 30, 3837-3855, 1996.

Sciare, J., D’Argouges, O., Esteve, R. S., Gaimoz, C., Dolgorouky, C., Bonnaire, N., Favez, O., Bonsang, B., and Gros, V.: Large contribution of water insoluble secondary organic aerosols in the region of Paris (France) during wintertime, J. Geophys. Res., 116, D22203, doi:10.1029/2011JD015756, 2011.

Sun, Y. L., Wang, Z. F., Fu, P. Q., Yang, T., Jiang, Q., Dong, H. B., Li, J., and Jia, J. J.: Aerosol composition, sources and processes during wintertime in Beijing, China, Atmos. Chem. Phys., 13, 4577-4592, doi:10.5194/acp-13-4577-2013, 2013.

Szidat, S., Jenk, T. M., Synal, H.-A., Kalberer, M., Wacker, L., Hajdas, I., Kasper-Giebl, A., and Baltensperger, U.: Contributions of fossil fuel, biomass burning, and biogenic emissions to carbonaceous aerosols in Zurich as traced by 14C, J. Geophys. Res., 111, D07206, doi:10.1029/2005JD006590, 2006.

Transport for London (TfL): London Low Emission Zone Impacts Monitoring Baseline Report, July 2008, Transport for London, London, UK, 2008.

Ulbrich, I. M., Canagaratna, M. R., Zhang, Q., Worsnop, D. R., and Jimenez, J. L.: Interpretation of organic components from Positive Matrix Factorization of aerosol mass spectrometric data, Atmos. Chem. Phys., 9, 2891-2918, doi:10.5194/acp-9-2891-2009, 2009.

Wagener, S., Langner, M., Hansen, U., Moriske, H. J., and Endlicher, W. R.: Spatial and seasonal variations of biogenic tracer compounds in ambient $\mathrm{PM}_{10}$ and $\mathrm{PM}_{1}$ samples in Berlin, Germany, Atmos. Environ., 47, 33-42, 2012.

Weimer, S., Alfarra, M. R., Schreiber, D., Mohr, M., Prévôt, A. S. H., and Baltensperger, U.: Organic aerosol mass spectral signatures from wood burning emissions: Influence of burning conditions and wood type, J. Geophys. Res., 113, D10304, doi:10.1029/2007JD009309, 2008.

Yin, J., Harrison, R. M., Chen, Q., Rutter, A., and Schauer, J. J.: Source apportionment of fine particles at urban background and rural sites in the UK atmosphere, Atmos. Environ., 44, 841-851, 2010.

Yin, J., Cumberland, S. A., Harrison, R. M., Allan, J., Young, D. E., Williams, P. I., and Coe, H.: Receptor modelling of fine particles in southern England using CMB including comparison with AMS-PMF factors, Atmos. Chem. Phys., 15, 2139-2158, doi:10.5194/acp-15-2139-2015, 2015.

Yttri, K. E., Dye, C., Siørdal, L. H., and Braathen O.-A.: Quantification of monosaccharide anhydrides by liquid chromatography combined with mass spectrometry: application to aerosol samples from an urban and a suburban site influenced by smallscale wood burning, J. Air Waste Manage., 55, 1169-1177, doi:10.1080/10473289.2005.10464720, 2005.

Yokelson, R. J., Griffith, D. W. T., and Ward, D. E.: Openpath Fourier transform infrared studies of large-scale labo- 
ratory biomass fires, J. Geophys. Res., 101, 21067-21080, doi:10.1029/96jd01800, 1996.

Young, D. E., Allan, J. D., Williams, P. I., Green, D. C., Flynn, M. J., Harrison, R. M., Yin, J., Gallagher, M. W., and Coe, H.: Investigating the annual behaviour of submicron secondary inorganic and organic aerosols in London, Atmos. Chem. Phys. Discuss., 14, 18739-18784, doi:10.5194/acpd-14-18739-2014, 2014.

Zhang, H., Wang, S., Hao, J., Wan, L., Jiang, J., Zhang, M., Mestl, H. E. S., Alnes, L. W. H., Aunan, K., and Mellouki, A. W.: Chemical and size characterization of particles emitted from the burning of coal and wood in rural households in Guizhou, China, Atmos. Environ., 51, 94-99, doi:10.1016/j.atmosenv.2012.01.042, 2012.

Zhang, J. K., Sun, Y., Liu, Z. R., Ji, D. S., Hu, B., Liu, Q., and Wang, Y. S.: Characterization of submicron aerosols during a month of serious pollution in Beijing, 2013, Atmos. Chem. Phys., 14, 2887-2903, doi:10.5194/acp-14-2887-2014, 2014.
Zhang, Q., Worsnop, D. R., Canagaratna, M. R., and Jimenez, J. L.: Hydrocarbon-like and oxygenated organic aerosols in Pittsburgh: insights into sources and processes of organic aerosols, Atmos. Chem. Phys., 5, 3289-3311, doi:10.5194/acp-5-32892005, 2005.

Zhang, Q., Jimenez, J. L., Canagaratna, M. R., Allan, J. D., Coe, H., Ulbrich, I., Alfarra, M. R., Takami, A., Middlebrook, A. M., Sun, Y. L., Dzepina, K., Dunlea, E. J., Docherty, K. S., Decarlo, P. F., Salcedo, D., Onasch, T., Jayne, J. T., Miyoshi, T., Shimono, A., Hatakeyama, S., Takegawa, N., Kondo, Y., Schneider, J., Drewnick, F., Borrmann, S., Weimer, S., Demerjian, K. L., Williams, P., Bower, K. N., Bahreini, R., Cottrell, L., Griffin, R. J., Rautiainen, J., Sun, J. Y., Zhang, Y. M., and Worsnop, D. R.: Ubiquity and dominance of oxygenated species in organic aerosols in anthropogenically-influenced Northern Hemisphere midlatitudes, Geophys. Res. Lett., 34, L13801, doi:10.1029/2007GL029979, 2007. 